\title{
Entrepreneurial Tenacity and Self-Efficacy Effects on Persisting Across Industry Contexts
}

\author{
James R. Van Scotter II \\ College of Business, University of Colorado Colorado Springs \\ E-Mail: jvanscot@uccs.edu \\ Swapnil Garg \\ Indian Institute of Management \\ E-Mail: swapnilgarg@iimidr.ac.in
}

\begin{abstract}
This study examines trait and context antecedents of entrepreneurial persistence in new venture creation. Two personality traits, entrepreneurial self-efficacy and tenacity, differently impact subsequent entrepreneurial persistence behavior in different industry contexts. These relationships are tested using logistic regression in a sample of entrepreneurs from the Panel Study of Entrepreneurial Dynamics (PSED-II; Curtin \& Reynolds, 2018). In developing the PSED-II dataset, 31,845 individuals were screened using phone interviews in order to identify a sample of 1,214 nascent entrepreneurs. Results of the current study identify significant relationships between entrepreneurial persistence in efforts to launch a new business and entrepreneurial self-efficacy and tenacity. However, the relationships have diminishing returns and vary with the industry context of the business (manufacturing, retail, services). In the retail industry sector, neither trait was significant; however, in manufacturing industry contexts, tenacity seems to matter more for continuing to pursue new ventures than self-efficacy, while in services industries, self-efficacy seems to matter more than tenacity.
\end{abstract}

Keywords: Tenacity, Entrepreneurial self-efficacy, Persistence, Start-up, Pre-launch, Manufacturing

\section{INTRODUCTION}

Do different entrepreneurial personality traits affect the decision to continue, or abandon, entrepreneurial startup efforts in different ways across different startup industry contexts? This study focuses on the pre-launch phase of opportunity 
exploitation. This initial phase presents the first evidence of entrepreneurial intentions and the first attempt to move from opportunity recognition to exploitation via new business formation. Only those who persist have a chance of becoming successful entrepreneurs. Using the PSED-II dataset (Curtin \& Reynolds, 2018), this paper identifies entrepreneurial persistence behavior as the act of continuing, persevering rather than abandoning, the entrepreneurial efforts and intentions over six years.

This study tests hypotheses about how entrepreneurial personality traits and industry contexts affect entrepreneurial persistence, extending prior research by Hopp and Sonderegger (2015). Following Davidsson and Gordon's (2012) call for future research, this study considers the non-linear effects of predictor variables (personality traits) and makes use of longitudinal information in conceptualizing the relationship between independent variables and the dependent variable. It also builds on conceptual work on perseverance (van Gelderen, 2012) by introducing industry start-up complexity as a key aspect of adversity and by conceptualizing entrepreneurial persistence as a behavior (i.e., not quitting) distinct from personality, but still associated with personality traits (e.g., grit, tenacity, self-efficacy). This study also extends research on organizational emergence at the pre-launch stage (Baron, 2007). This study also extends recent research published in Contemporary Management Research by examining this early pre-launch stage of new venture formation that spans from idea generation through the launch of the new startup, a time when many entrepreneurs abandon their efforts (Lin, Lu, Hsieh \& Liu, 2018). Finally, it addresses aspects of opportunity exploitation that researchers have been calling for (Shane \& Venkataraman, 2000).

\section{THEORETICAL BACKGROUND}

Entrepreneurship presents numerous highly challenging situations that must be overcome for entrepreneurs to achieve their goals (Baron, 2007; Gatewood et al., 1995). To achieve success, entrepreneurs must be persistent with their actions in all phases of the entrepreneurial process, despite the ambiguity, uncertainty, inevitable setbacks, and disappointments. Different phases of the entrepreneurial process are associated with different types of goals and outcomes (Baron, 2007), and the pre-launch phase is when ideas develop into entrepreneurial intentions. In this phase, entrepreneurs begin to initiate actions, despite uncertainty and ambiguity; however, many of these initiatives fail to achieve intended results. Perseverance increases the number of actions taken by the entrepreneur, increases experience, facilitates learning and engaging in more informed actions, and creates opportunities for subsequent successes. Abandonment, or the decision not to persist, is deeply related to personality and individual differences.

\section{Entrepreneur Personality Characteristics}


Entrepreneurship researchers have studied the relationship between broad personality dimensions and entrepreneurial success empirically, such as the Big Five (Zhao \& Seibert, 2006), and specific personality traits like the need for achievement (Wu \& Dagher, 2007), and risk propensity (Stewart \& Roth, 2001). Examining the link between broad and narrow personality traits, Markman (2007) modeled the entrepreneurs' competencies as a set of knowledge, skills and abilities. Results suggested that entrepreneurial knowledge, skills and abilities emerge from broad personality characteristics and combine with specific entrepreneurial personality traits to support success in business creation (Rauch \& Frese, 2007). Moreover, Trevelyan (2011) suggested that positive traits, such as self-efficacy, are beneficial to entrepreneurship, while other types of entrepreneurial traits (e.g., promotion vs. prevention focus) have a high probability of being helpful in different entrepreneurial task contexts (e.g., exploration vs. exploitation).

A significant challenge for entrepreneurs is that the process of taking a business idea from the initial concept entirely to launch often requires considerable time, perhaps many years, a willingness to face setbacks and failures and to have the ability to adapt with new iterations when necessary (Meek \& Williams, 2018). Rauch and Frese (2007) concluded that the five traits, which are self-efficacy, tenacity, proactive personality, need for achievement, and passion for work are important in the entrepreneurial context. Moreover, they found tenacity was consistently rated as the most important trait, rated 4.4 on a scale of five, with high inter-rater reliability ( $\mathrm{rwg}=.87$ ). This high rwg statistic signifies a very high level of within-group agreement among the 10 business experts in the study, and suggests experts agree that tenacity is important for entrepreneurship. Entrepreneurial self-efficacy (ESE) and entrepreneurial tenacity (ET) seem to be explicitly entrepreneurial traits, distinct from other personality traits.

\section{Context of Entrepreneurship}

The relevance of situational and contextual factors for studies examining the relationships between traits and behaviors has long been accepted (Mischel 1977; Mischel \& Shoda, 1995). The organizational design literature focuses on industry environment dynamism, munificence and complexity (Dess \& Beard, 1984), and finds that context affects managerial and organizational behavior. Hmieleski and Baron (2006, 2009), studied how environmental dynamism affects the link between entrepreneurial traits and behaviors. While these authors capture the environment in terms of dynamism and stability, many other environmental dimensions have been examined in other kinds of literature, but remain unexplored in the entrepreneurship 
context. The role of context has been explored in the entrepreneurship literature across various dimensions: social environment (Baker et al. 2005), environmental dynamism (Hmieleski \& Baron, 2006), and institutions (Boettke \& Coyne, 2009). This study extends this literature by examining the role of the industry context in which the entrepreneur attempts to create the new venture and how different entrepreneurial personality traits influence the decision to continue striving, or not, in these different industry contexts.

\section{HYPOTHESIS DEVELOPMENT}

\section{Entrepreneurial Persistence Behavior}

The entrepreneurial startup process presents complex challenges that often remain ambiguous and unstructured for a more extended duration of time, and presents levels of complexity that vary across different types of startup contexts. In one of the first studies on the subject, Seligman and Schulman (1986) found that life insurance sale agents are less likely to persevere with their jobs if they follow a pessimistic life explanatory style, compared to if they follow an optimistic life explanatory style. The importance of persistence behavior has been recognized for new venture creation (Markman \& Baron, 2003), but its antecedents in the entrepreneurial context have not been systematically studied. While the authors of this study were unable to locate any published research exploring antecedents of entrepreneurial persistence behavior in the pre-launch phase, it seems likely that a positive entrepreneurial disposition may facilitate commitment and persisting.

The number of entrepreneurship studies that examine persistence behavior is limited, and most of them study at the firm level (e.g., DeTienne et al. 2008; Gimeno et al. 1997), or examine persistence without distinguishing between the phase of the startup (e.g., Cardon \& Kirk, 2015), or examine the role of other cognitive attributes (e.g., Dimov 2010; Farmer et al. 2011; Gatewood et al. 1995; Holland \& Shepherd, 2013). Even though these studies contribute knowledge about entrepreneurial persistence, there is still a need for further investigating how various types of positive personality dispositions - ET and ESE - influence persistence in different startup industry contexts, especially in the pre-launch phase.

\section{Entrepreneurial Self-Efficacy}

Self-efficacy is a cognitive construct reflecting a person's confidence in his or her ability to perform a task and has been empirically shown to be associated with a broad range of behaviors and cognitions (Bandura, 2001). Recognizing that self-efficacy can be task-specific or generalized, Cassar and Friedman (2009) define entrepreneurial self- 
efficacy as the confidence that individuals have in their ability to accomplish tasks specific to the domain of entrepreneurship.

ESE has been argued to reflect the cognitive styles, intuition versus analysis, of individuals (Kickul et al., 2009). Female and male students have been found to differ in ESE (Baughn et al., 2006). It has been identified as one of the key points of difference between managers and entrepreneurs (Chen et al., 1998) and also between inventors and entrepreneurs (Markman et al., 2005); however; a recent study presented contradictory evidence (Hurst 2019) such that a nuanced examination of the relationships seems prudent and timely. It also affects the development of entrepreneurial intentions (Zhao et al. 2005), leads to firm performance (Hmieleski \& Baron, 2008) and also affects the extent to which aggressive entrepreneurial investments are made (Cassar \& Friedman, 2009).

Several studies have reported associations between ESE or general self-efficacy with new venture performance (e.g., Baum \& Locke 2004; Smith et al., 2001) or entrepreneurial intention (Zhao et al. 2005). As ESE reflects an entrepreneur's belief in his or her self, and belief in the ability to deliver positive results, entrepreneurs with more self-efficacy will probably be more likely to persist in their pre-launch efforts rather than abandon them.

\section{Entrepreneurial Tenacity}

ET is a personality trait related to entrepreneurship outcomes that has not been sufficiently studied in the entrepreneurship literature (Rauch \& Frese, 2007). According to the definition provided by Baum and Locke (2004), tenacity "is a trait that involves sustaining goal-directed action and energy even when faced with obstacles" (p. 588). Baum et al. (2001) studied entrepreneurial firms in the architectural woodworking industry. They found a direct positive association between CEO tenacity and venture growth and an indirect effect of CEO tenacity on general and specific competency and situation-specific motivation. Baum and Locke (2004) found that tenacity affects venture growth directly and indirectly through its effects on self-efficacy, goals and communicated vision. Both of these studies modeled the association between CEO tenacity and venture growth; however, unlike the current study, they focused on the post-launch phase rather than the pre-launch phase of venture creation.

Tenacity has been studied under different labels in the psychology literature. Stolz's (1997) adversity quotient measure, consisting of 30 scenario-based questions, reflects the notion that success requires persisting in challenging and obstacle-riddled environments. Markman et al. (2005) give tenacity the label of entrepreneurial 
perseverance, a trait consisting of perceived control over adversity and perceived responsibility regarding outcomes of adversity, and define it as one's tendency to persist and endure in the face of adversity. They found that entrepreneurs' perseverance was related to founding new business ventures, overcoming setbacks, achieving higher annual earnings, and found that entrepreneurs were significantly different from nonentrepreneurs in their level of perseverance.

\begin{tabular}{|c|c|}
\hline Entrepreneurial Self-Efficacy (ESE) & $\begin{array}{c}\text { Job Demands due to Industry Context } \\
\text { Manufacturing Sector } \\
\text { Retail Sector } \\
\text { Services Sector } \\
\end{array}$ \\
\hline Entrepreneurial Tenacity (ET) & \\
\hline $\begin{array}{l}\quad \text { CONTROL VARIABLES: } \\
\text { Startup Characteristics } \\
\text { Stage of Startup } \\
\text { Individual Characteristics } \\
\text { Age, Marital Status, Experience, } \\
\text { Gender, Race, Fulltime Effort } \\
\text { Support Characteristics } \\
\text { Parents owned a business } \\
\text { Support (family or non-family) }\end{array}$ & $\begin{array}{c}\text { Persistence } \\
\text { Behavior }\end{array}$ \\
\hline Entrepreneurial Persistence Behavior & $\begin{array}{l}\text { This behavior is defined by the act of } \\
\text { continuing to persist in pursuing the } \\
\text { entrepreneurial venture (i.e., not } \\
\text { quitting) over the six-year study period. }\end{array}$ \\
\hline Entrepreneurial Self-Efficacy & $\begin{array}{l}\text { Cognitive construct reflecting } \\
\text { confidence in one's ability to accomplish } \\
\text { tasks in the domain of entrepreneurship. }\end{array}$ \\
\hline Entrepreneurial Tenacity & $\begin{array}{l}\text { Trait reflecting the tendency to persist, } \\
\text { endure, and sustain goal-directed } \\
\text { behavior when faced with adversity. }\end{array}$ \\
\hline
\end{tabular}

Figure 1. Conceptual Model for Entrepreneur Traits and Persistence Behavior

The importance of tenacity in the entrepreneurial context has been recognized (see Markman, 2007, for a review), but has not been sufficiently studied in the pre-launch phase. In this phase, ET may be defined as an entrepreneur's trait of fighting against all odds, refusing to give up and tenaciously working towards the objective, despite the 
uncertainty and ambiguity. Chandler and Jansen (1992) constructed a self-report measure they called drive, indicating the drive to achieve the completion of a new business launch, but the businesses they studied were expanding mature businesses in the post-launch phase. Duckworth et al. (2007) examined another similar concept, which they called grit, defined as "perseverance and passion for long-term goals. Grit entails working strenuously toward challenges, maintaining effort and interest over the years despite failure, adversity, and plateaus in progress" (pp. 1087-1088). Different from self-efficacy, the trait of tenacity and these other conceptually similar traits do not address self-confidence, ability, or belief, but rather encompass the dogged and relentless nature of individuals who refuse to give up. Hence, in the pre-launch phase of entrepreneurship, ET is likely to lead an entrepreneur to persist in a pattern of actions despite experiencing the frequent negative cues and ambiguities associated with prelaunch start-up efforts.

\section{Diminishing Returns of Entrepreneurial Self-Efficacy and Tenacity}

Entrepreneurs are more optimistic than others in the population (Gartner, 2004). However, excessive optimism or overconfidence could put entrepreneurs at risk of irrational exuberance (Cheng \& Liao, 2017). Entrepreneurs' optimism toward the future moderates the effects of ESE on venture growth (Hmieleski \& Baron, 2008) such that high self-efficacy and excessive optimism may exert negative effects. As both selfefficacy and optimism tap into one's sense of confidence, high levels of ESE may reflect excessive optimism. The requirement for non-routine problem solving, task complexity, and other challenges of orchestrating organizational emergence suggest that successful entrepreneurs should have at least moderate levels of ESE and ET. However, given the relevance of other external factors such as market conditions and resource constraints, it is likely that beyond a threshold level of these traits, increasingly higher levels of ESE and ET may not predict additional persistence. Therefore, the effects of ESE and ET on the decision to continue persisting with entrepreneurial efforts may tend to diminish beyond a certain level.

Hypothesis 1: The relationship between entrepreneurial self-efficacy and persistence is inverse curvilinear such that positive effects of self-efficacy on persistence will diminish as entrepreneurial self-efficacy rises to a high level.

Hypothesis 2: The relationship between entrepreneurial tenacity and persistence is inverse curvilinear such that positive effects of tenacity on persistence will diminish as entrepreneurial tenacity rises to a high level. 


\section{Industry Context, Personality Traits, and Entrepreneurial Persistence}

Entrepreneurship startups face diverse challenges. The industry context is a critical antecedent that affects the performance of the startup, e.g., the timing of organizational emergence, pre-established startup complexity, risk, or failure rates of startups. Prior studies have noted significant differences in failure rates across the manufacturing, services, and retail industry sectors (Fredland \& Morris, 1976; Lowe et al., 1991; Watson \& Everett, 1999). Startups in different industry sectors follow different prelaunch time horizons, and differ in the duration and sequence of activities. For example, technology-intensive ventures often require longer gestation duration with technologybased entrepreneurs engaging in more planning activities, legitimacy establishment, and resource acquisitions (Liao \& Welsch, 2003). While business launches in the manufacturing and agriculture sectors need a high amount of initial investments in plant, machinery or land assets, service delivery and retailing can be attempted with relatively smaller upfront investments. Therefore, the traits of ESE and ET should probably differ in their relevance for persisting in efforts to launch a new business across manufacturing, retail, and service industry sectors.

\section{Tenacity and Persistence in Launching Manufacturing Ventures}

Larger initial investments for manufacturing sector businesses may slow the process of organizational emergence due to the additional complexity. For example, the need to secure financing from creditors and investors may slow the launch. Likewise, new organizational launches requiring limited liability protections, loan debt, equity investment, and other complex transactions are more likely to require more complex corporate legal forms of organization (Demirguc-Kunt et al., 2006). There are also operational challenges typically associated with manufacturing businesses, such as the need to consider patent approvals, intellectual property protections, safety and environmental regulations, and other administrative hurdles that must be overcome. Therefore, the complexity of setting up a business in the manufacturing sector is likely to require a more tenacious form of endurance to facilitate entrepreneurial persistence over time amidst the challenges of operational complexity and administrative red tape. Specifically, this suggests ET will be associated with persistence in launching new manufacturing ventures; however, as previously discussed, there may also be diminishing returns to the effects of ET.

Hypothesis 3a: For entrepreneurs involved in manufacturing, tenacity will be associated with persistence in efforts to launch a new manufacturing venture. 
Hypothesis 3b: There will be an inverse curvilinear relationship between tenacity and persistence in founding a manufacturing venture reflecting the diminishing returns of tenacity for continued persistence.

\section{Self-efficacy and Persistence in Launching Retail and Service Ventures}

Retail and service sector businesses, having a comparatively lower level of complexity than manufacturing, are more likely to be among the $70 \%$ of businesses that are organized as unincorporated sole proprietorships (Beesley, 2013). The majority of these businesses are generally less capital intensive, less likely to require a complex SCorp or C-Corp structure, and have fewer administrative and regulatory hurdles than manufacturing businesses. Therefore, since the level of complexity is somewhat lower, the personality trait of ET that supports entrepreneurial persistence in the manufacturing sector may not be as predictive of entrepreneurial persistence behavior in service and retail business launches. On the other hand, self-efficacy has shown the strongest correlation with performance when task complexity is low (Stajkovic \& Luthans, 1998). Past studies have also demonstrated a relationship between ESE and being a business founder. For example, in a sample consisting mostly of retail and service sector businesses (only 12.7 percent of the sample was manufacturing), Chen et al. (1998) found that ESE significantly differentiated business founders from business managers. Hence, ESE may likely be associated with persistence in founding new ventures in retail and service sectors but may not matter much for persisting in efforts to launch manufacturing ventures. Building on the prior discussion, there will likely be diminishing returns for the effects of ESE on persistence in efforts to launch a new business venture in the retail or services sectors.

Hypothesis 4a: For entrepreneurs involved in product retail or service industry contexts, entrepreneurial self-efficacy will be associated with persistence in startup efforts.

Hypothesis 4b: There will be an inverse curvilinear relationship between entrepreneurial self-efficacy and persistence in founding a retail or service venture reflecting the diminishing returns of entrepreneurial self-efficacy for continued persistence.

\section{METHODS}

\section{PSEDII Sample}

Data from a nationally representative sample of nascent U.S. entrepreneurs was obtained from the Panel Study of Entrepreneurial Dynamics (PSED-II) (Curtin \& 
Reynolds, 2018). During this study, 31,845 individuals were randomly selected and screened to identify if they were involved in any sort of new firm creation. Of those identified, 87 percent agreed to participate in the study and 1,214 entrepreneurs were telephonically interviewed over six years at 12-month intervals between 2005 and 2011. Each of the telephonic surveys used a structured format. Entrepreneurs were asked a wide range of questions which sought to identify the antecedents and processes involved in entrepreneurship: conditions of opportunity recognition, demographics, dispositional and motivational attributes of the entrepreneur, social support network of the entrepreneur, sources of funding, actual activities carried out and expectations of the entrepreneur from the new business. The codebook and dataset for the initial survey and follow up interviews conducted between 2005 and 2011 are in the public domain. The survey administrators took care to survey the respondents one year apart (Curtin, 2012).

Longitudinal studies are of this type are often plagued with problems of sample attrition. The PSED-II sample used in this study started with 1214 nascent entrepreneurs. This sample reduced to 972, 746, and 527, 435 and 375 over the successive waves of interviews. As a result, the current study focused only on the entrepreneurs for whom full information was available, while also taking steps to address the issue of missing data. When nascent entrepreneurs went missing from the sample, but later returned, their statuses were recorded in the intermediate stages. This yielded clear status information on 978 of the 1214 nascent entrepreneurs originally identified. As a robustness check, a subsample t-test was done in order to discover whether the subsample of 978 entrepreneurs differed from the full sample of 1214. No significant difference was found with respect to age, sex, race, education or marital status of the entrepreneur. Data collected from the first wave of interviews was used to construct the independent, moderating and control variables. The dependent variable, entrepreneurial persistence behavior, came from later waves and captured whether the nascent entrepreneur was actively persisting with efforts in the opportunity identified earlier, or if he or she had quit. Because the dependent variable of interest is dichotomous, it was appropriate to analyze the data using a logit model.

\section{Dependent Variable (Entrepreneurial Persistence Behavior)}

Entrepreneurial persistence behavior means continuing to work on developing the new business rather than abandoning efforts. Instead of basing the measure on firm formation as the end of the pre-launch phase, which can become ambiguous in the entrepreneurial context, the analysis that follows captures persistence information from those cases in which the entrepreneur abandoned their opportunity exploitation efforts. This measure unambiguously indicates whether the entrepreneur ceased pursuing an effort that had previously been considered attractive. Accordingly, entrepreneurial 
persistence is a dichotomous variable that captures whether the entrepreneurs quit or persisted in their efforts.

In the initial survey, 1,214 nascent entrepreneurs were identified, none of whom had yet founded a firm. In each follow-up wave of the questionnaire, nascent entrepreneurs were asked, "In what month and year did you end your active role in working on this (new) business (startup)?” (Curtin, 2012, p. 58). A seven-question exit interview was also conducted on these entrepreneurs, confirming their status.

\section{Measuring Entrepreneurial Tenacity}

In one of the first studies attempting to link entrepreneurs' personal characteristics with launching a new venture, Chandler and Jansen (1992) captured an individual's "drive to see firm creation through to fruition" (p. 227). This domain consisted of Likert scale items such as, "Make venture work no matter what," and "Refuse to let venture fail" (p. 228). In the current sample, responses were provided for two questions that were used in a prior study by Tang (2008) to indicate tenacity, behavioral commitment to an entrepreneurial venture. Respondents reported their level of agreement on a fivepoint Likert scale. The questions were a) "There is no limit as to how long I would give maximum effort to establish this new business" and b) "My Personal philosophy is to "do whatever it takes" to establish my own business" (p. 137). Liao and Welsh (2004) used these same items in a measure labeled entrepreneurial intensity, and Dimov (2010) used the same items to measure a construct labeled start-up motivation. MerriamWebster (2018) describes tenacity, or tenacious, as "persistent in maintaining, adhering to, or seeking something valued or desired... not easily stopped or pulled apart... continuing for a long time... very determined to do something." The concept of tenacity seems to be a more apt descriptive label for the latent personality construct indicated by the aforementioned PSED-II items. These two questions have reliability of $(\alpha=.70)$ on both the full sample and selected sample of 978 nascent entrepreneurs for whom full information was available.

\section{Measuring Entrepreneurial Self-Efficacy}

Cassar and Friedman (2009) assessed the construct validity of an ESE measure using survey responses from samples of 830 nascent entrepreneurs and 125 undergraduate students. Their measure of ESE had convergent validity with the measure of ESE used by Chen et al. (1998), having a raw correlation $r=.52$. They also found discriminant validity with overconfidence, generalized self-efficacy, locus of control, dispositional optimism, self-esteem and core self-evaluations, as it had correlation 
coefficients of less than 0.30 with these measures. The measure used in the current study contained three of the four items used by Cassar and Friedman (2009), "If I work hard, I can successfully start a business," "Overall, my skills and abilities will help me start a business," and "My Past experience will be very valuable in starting a business" (p. 247). The fourth item was not available in the PSED-II dataset. The Cronbach's alpha for the three survey items was $(\alpha=.71)$, both in the full sample of nascent entrepreneurs and also in the selected sample of 978 entrepreneurs on whom full status information was available.

\section{Context of Entrepreneurship}

The dataset also captures the two-digit SIC codes of the industry in which the entrepreneur is trying to form a venture. In the dataset of 978 entrepreneurs with full information, there were 220 entrepreneurs involved in the manufacturing sector, 235 entrepreneurs involved in the retail sector, and 521 entrepreneurs in the services sector.

\section{Controls}

Hmieleski and Baron $(2008,2009)$ found that environmental dynamism moderates the relationship between ESE and venture growth. To control for environmental effects, the geographic region (North, South, East, or West) in which the entrepreneur is operating was controlled. Baron's (2007) process perspective also identified social environment variables as affecting entrepreneurial performance. Cassar and Friedman (2009) and Kim et al. (2006) used a dummy variable for whether or not the parents were self-employed as a proxy for the social and cultural capital of the entrepreneur. These variables were included in the current study to cover, as far as possible, the range of societal level variables previously investigated in the literature.

Existing entrepreneurial studies were surveyed for the use of suitable control variables. Controls were included for the entrepreneur's age, sex, marital status, race, education level, full-time involvement, expertise levels, and previous business-owning experience in the analysis. Other aspects of the entrepreneur's ability that could affect entrepreneurial persistence behavior were controlled, such as the number of entrepreneurial activities completed before entering the survey and whether the entrepreneur's parents ever owned a business. Further, entrepreneurs are provided support by their kin and non-kin supporters in their efforts. Therefore, the total number of people providing support to the entrepreneur was controlled.

\section{Analysis}

The dependent variable in the study is entrepreneurial persistence. In the analyzed sample of 978 entrepreneurs, there exist 648 instances of quitting and 330 instances of 
persistence by the entrepreneurs. In 143 instances, entrepreneurs had formed a firm and were continuing to persist with their new venture by the last wave of the survey. These were included in the group of persisting entrepreneurs. Thus, continuing to persist in entrepreneurial efforts was modeled as a dichotomous dependent variable (zero if quit, and one if still persisting).

The context of entrepreneurship is modeled as a nominal variable, that is, one for manufacturing and agriculture, two for retail, and three for services. The sample was split in order to study the moderating effects of the different contexts. Sufficient sample sizes of 200 observations, or more, for each industry context of the sub samples facilitated this analysis, however, due to different sample sizes, it would be inappropriate to compare the size of the coefficients between the samples.

\section{RESULTS}

The correlation matrix presented in Table 1, reveals interesting relationships. While ET and ESE were significantly correlated with each other, the magnitude of the correlation, $\mathrm{r}=.39$, was not high enough to raise concerns about whether the measures were sufficiently distinct from each other. For example, Baum and Locke (2004), also found a significant correlation between tenacity and self-efficacy $r=.20, p<.01$ ). Likewise, Baum et al. (2001) found correlations between tenacity, the "drive to see firm creation through to fruition," and self-reported opportunity recognition competence (r $=.32, \mathrm{p}<.01)$ and correlation between tenacity and self-reported human (entrepreneurial) competence $\mathrm{r}=.22, \mathrm{p}<.05$ ). 
TABLE 1. Descriptive Statistics and Correlations of the Variables ${ }^{\text {a }}$

\begin{tabular}{|c|c|c|c|c|c|c|c|c|c|c|c|c|}
\hline & & Min & Max & Mean & $S D$ & 1 & 2 & 3 & 4 & 5 & 6 & 7 \\
\hline 1 & Stage of Startup & 0 & 23 & 6.97 & 4.12 & & & & & & & \\
\hline 2 & Age & 18 & 83 & 43.57 & 12.88 & 0.08 & & & & & & \\
\hline 3 & Education & 8 & 20 & 14.51 & 2.30 & 0.21 & 0.25 & & & & & \\
\hline 4 & $\begin{array}{l}\text { Experience (years- } \\
\text { General) }\end{array}$ & 0 & 54 & 9.38 & 10.60 & 0.08 & 0.35 & 0.09 & & & & \\
\hline 5 & $\begin{array}{l}\text { Experience } \\
\text { (Entrepreneurial) }\end{array}$ & 0 & 25 & 1.02 & 1.94 & 0.20 & 0.23 & 0.15 & 0.12 & & & \\
\hline 6 & $\begin{array}{l}\text { Experience } \\
\text { (Ownership) }\end{array}$ & 0 & 7 & 0.31 & 0.77 & 0.16 & 0.15 & 0.16 & 0.05 & 0.58 & & \\
\hline 7 & $\begin{array}{l}\text { Entrepreneurial Self } \\
\text { Efficacy (ESE) }\end{array}$ & 1.67 & 5 & 4.47 & 0.54 & 0.08 & 0.02 & 0.06 & 0.23 & 0.10 & 0.03 & \\
\hline 8 & $\begin{array}{l}\text { Entrepreneurial } \\
\text { Tenacity (ET) }\end{array}$ & 1 & 5 & 3.09 & 0.85 & 0.00 & -0.08 & -0.19 & 0.07 & -0.02 & -0.08 & 0.39 \\
\hline
\end{tabular}

${ }^{\mathrm{a}} N=978$, All correlations significant at less than $p<0.05$ are in bold

TABLE 2. Descriptive Statistics for the Dichotomous Variables

\begin{tabular}{c|lcccc}
\hline & & Min & Max & Mean & SD \\
\hline 1 & Persistence Behavior & 0 & 1 & 0.26 & 0.44 \\
2 & Male & 0 & 1 & 0.63 & 0.48 \\
3 & White & 0 & 1 & 0.84 & 0.36 \\
4 & Married & 0 & 1 & 0.62 & 0.49 \\
5 & Fulltime Involvement & 0 & 1 & 0.29 & 0.46 \\
6 & Parents Owned Business & 0 & 1 & 0.52 & 0.50 \\
7 & Support Reported (Y/N) & 0 & 1 & 0.61 & 0.49 \\
\hline$N=978$ & & & & &
\end{tabular}

In hypothesis 1, a curvilinear relationship was expected, with diminishing returns, between ESE and entrepreneurial persistence. The effects of ESE were positive ( $\beta=$ $6.40, \mathrm{p}<.05)$, inverse curvilinear $(\beta=-0.72, \mathrm{p}=.05)$, offering support for this hypothesis. In hypothesis 2 , a curvilinear relationship was expected, with diminishing returns, between ET and persistence. In results from model 3, the relationship was positive $(\beta=1.07$, n.s.), but the inverse curvilinear effect was only marginally significant $(\beta=-0.15, p<.10)$, offering only marginal support for this hypothesis. The failure to find strong support for this part of the hypothesis was not completely unexpected, because entrepreneurial traits may vary in their relevance for predicting success across different types of entrepreneurial startup contexts. 
TABLE 3.

Logistic Regression: Trait and Contextual Effects on Entrepreneurial Persistence

\begin{tabular}{|c|c|c|c|c|c|c|c|}
\hline & Model O & Model 1 & Model 2 & Model 3 & Model 4 & Model 5 & Model 6 \\
\hline Sample Size & 978 & 978 & 976 & 976 & 220 & 235 & 521 \\
\hline Stage of Startup & $0.06 * *$ & $0.06 * *$ & $0.06 * *$ & $0.06 * *$ & 0.06 & 0.04 & $0.08 * *$ \\
\hline \multicolumn{8}{|l|}{ Entrepreneur } \\
\hline \multicolumn{8}{|l|}{ Characteristics } \\
\hline Male & -0.16 & -0.16 & -0.16 & -0.18 & 0.12 & -0.36 & -0.29 \\
\hline Age & $0.02 *$ & $0.02 *$ & $0.02 *$ & $0.02 *$ & 0.01 & 0.02 & $0.02 *$ \\
\hline White & $-0.35 \dagger$ & $-0.34 \dagger$ & $-0.36 \dagger$ & -0.33 & 1.00 & -0.59 & $-0.51 *$ \\
\hline Married & 0.03 & 0.03 & 0.04 & 0.04 & 0.34 & 0.18 & -0.07 \\
\hline Education & $0.09 * *$ & $0.09 * *$ & $0.09 *$ & $0.09 *$ & 0.09 & 0.03 & $0.10 *$ \\
\hline Fulltime Involvement & $0.43^{*}$ & $0.42 *$ & $0.45 * *$ & $0.43^{*}$ & $1.28 * * *$ & 0.45 & 0.09 \\
\hline Experience (General) & $0.03 * * *$ & $0.03^{* * *}$ & $0.03 * * *$ & $0.03 * * *$ & $0.04 * *$ & 0.00 & $0.03 * *$ \\
\hline $\begin{array}{l}\text { Experience } \\
\text { (Entrepreneurial) }\end{array}$ & -0.03 & -0.04 & -0.03 & -0.03 & -0.07 & 0.04 & -0.07 \\
\hline Experience (Ownership) & 0.08 & 0.08 & 0.08 & 0.06 & $-0.80^{*}$ & 0.10 & 0.15 \\
\hline \multicolumn{8}{|l|}{ Support } \\
\hline Parents Owned Business & -0.05 & -0.05 & -0.07 & -0.09 & $-0.95^{* *}$ & 0.34 & 0.09 \\
\hline Support Reported (Y/N) & 0.22 & 0.21 & 0.24 & 0.24 & 0.17 & 0.39 & 0.16 \\
\hline \multicolumn{8}{|l|}{ Hypothesized Variables } \\
\hline $\begin{array}{l}\text { Entrepreneurial Self } \\
\text { Efficacy (ESE) }\end{array}$ & & 0.09 & 0.13 & $6.40^{*}$ & -4.57 & 13.13 & $9.02 *$ \\
\hline Self Efficacy (Squared) & & & & $-0.72 *$ & 0.54 & -1.45 & $-1.03^{*}$ \\
\hline $\begin{array}{l}\text { Entrepreneurial Tenacity } \\
\text { (ET) }\end{array}$ & & & -0.06 & 1.07 & $2.80 \dagger$ & 3.86 & 0.15 \\
\hline Tenacity (ET) ( Squared) & & & & $-0.15 \dagger$ & $-0.44 * *$ & -0.44 & 0.03 \\
\hline Log Likelihood $* * *$ & -534.60 & -534.43 & -531.84 & -526.64 & -108.32 & -106.41 & -285.60 \\
\hline $\begin{array}{l}\text { Likelihood-Ratio } \\
\text { Chi2 *** }\end{array}$ & 73.52 & 73.86 & 73.80 & 84.20 & 46.86 & 25.12 & 57.86 \\
\hline
\end{tabular}

To see how industry context may influence the effect of entrepreneurial traits on persistence, the data were reanalyzed in each of the different industry contexts. Since power and sample size were sufficient, rerunning the analysis on industry sub-samples was feasible, and even more conservative, decreasing the likelihood of obtaining spurious statistical significance due to the larger sample size of the full sample. These results are presented in models 4,5 and 6 . For the sample of entrepreneurs pursuing manufacturing ventures, a positive $(\beta=2.80, \mathrm{p}<.10)$ and significant inverse curvilinear effect of ET $(\beta=-0.44, p<.05)$ was found. The result offers support for hypotheses $3 a$ and $3 \mathrm{~b}$ and suggests that the effect of ET is positive for persistence with founding manufacturing firms, but also that there are diminishing returns for ET. As anticipated, ESE was not a relevant factor in founding new manufacturing firms. 
In support of hypotheses $4 \mathrm{a}$ and $4 \mathrm{~b}$, ESE had a positive $(\beta=9.02, \mathrm{p}<.05)$ and significant inverse curvilinear relationship $(\beta=-1.03, p<.05)$ with persistence in founding business ventures in the services sector. As hypothesized, this relationship indicated a positive effect but also with diminishing returns for self-efficacy. Further, it was expected that ET would not significantly predict persistence in pursuing new venture launches in the services sector, and this expectation was confirmed. These hypotheses also predicted significant relationships between ESE and persistence in founding retail ventures; however, the hypotheses were not supported in this industry context.

Collectively, these findings indicate that an entrepreneur's personality attributes of ESE and ET lend some modest support for persistence in the pre-launch phase. Moreover, the findings suggest that these traits vary in their relevance across different industry contexts and that the traits appear to offer diminishing returns. To further explore the practical implications of these results, receiver operating characteristic (ROC) curves were plotted for the manufacturing and services sectors in order to determine the degree to which the independent variables in the logistic regression models correctly classified whether the entrepreneurs abandoned their pre-launch efforts or whether they persisted in their start-up efforts. The results for the retail sector are not reported here because the results for ESE and ET were not significant in that context; however, the data are available from the authors upon request. The results reported in figure 2 show that, in the manufacturing context, the logistic regression model correctly classified persistence versus quitting in $77.68 \%$ of the 220 cases, and in the services sector correctly classified $69.95 \%$ of the 521 cases. 

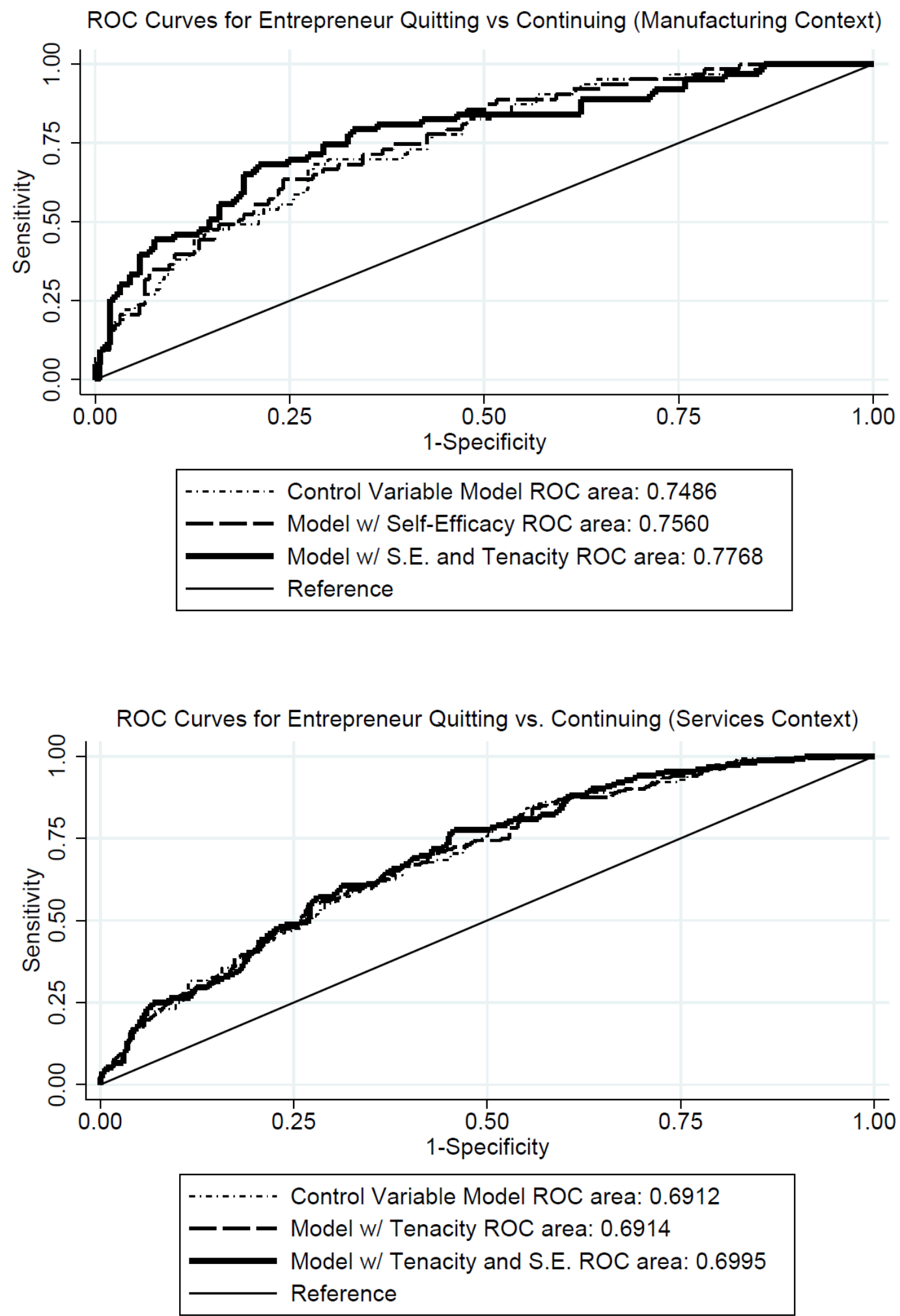

Figure 2.

ROC curves for Entrepreneur Tenacity and Self-Efficacy effects on Quitting 
The industry context does appear to play a role, as hypothesized; however, some of the relationships were inconsistent with expectations. One could reasonably conclude that industry context moderates the effects of trait variables on persistence behavior, though the precise mechanisms through which this occurs remain ripe for further exploration.

\section{DISCUSSION}

This study explored boundary conditions affecting the significance of entrepreneurial traits, which is critical for developing insights about how personality matters in the entrepreneurial context. In hypothesis 1, results show that ESE and ET have positive effects on persisting, but their contribution is limited such that increasingly higher levels of these positive traits present no additional benefit. Hypothesis 2 builds on this finding by identifying ET as a relevant trait for entrepreneurs pursuing a manufacturing startup, but finds no similar effect of ESE. This suggests interventions in the manufacturing context to help entrepreneurs develop resilience and the drive to never give up may be more beneficial than positive encouragement designed to enhance self-confidence in their ability to succeed. However, the results of hypothesis 3 show the opposite, that ESE matters more than tenacity in services contexts. Thus, entrepreneurs pursuing service industry ventures may benefit more from positive feedback designed to boost confidence in their entrepreneurial abilities than they would from interventions designed to build tenacious determination to never give up.

This study builds on recent theoretical work on the role of ESE in the pre-launch phase. Drnovšek, Wincent, and Cardon (2010), proposed that ESE consists of goal beliefs focused on outcomes and tasks and that goal beliefs about outcomes were more relevant than beliefs about tasks at the earliest stages: intent formation, opportunity recognition, and the decision to exploit. Drnovšek and colleagues also proposed that goal beliefs about tasks would be more relevant for opportunity exploitation, a proposition which seems well aligned with our supposition that greater task complexity in the manufacturing context effects the degree to which ESE matters, versus ET. Results presented in this paper suggest entrepreneurial traits, ESE and ET, have positive effects on entrepreneurial persistence at pre-launch, but their impact may depend on situational factors and may have diminishing returns. Entrepreneurial persistence studies had not empirically examined these trait relationships in the pre-launch phase, a time when uncertainty is highest and traits are likely to matter most. This paucity of empirical evidence can be partly attributed to the fact that clear and undisputed entrepreneurial trait measures, like ESE, are only recently emerging (Cassar \& Friedman, 2009; McGee et al., 2009). In order to further advance research examining 
entrepreneurial persistence behavior (i.e., not quitting or abandoning the startup effort) it is also critical for scholars to clarify significant semantic differences in terms (Davidsson, 2012), especially terms that can incorrectly be viewed as synonymous (e.g., tenacity - a personality trait; and persistence - a behavioral outcome determined by traits, motivations, contexts, and other factors).

\section{Implications for Research and Practice}

The industry context of entrepreneurship moderates the effects of trait variables. Welter (2011) argues that contexts can be described in terms of space, institutions, gender, societies, social environment, etc., and the influence of these dimensions needs to be specifically theorized. The initial empirical evidence presented in this study suggests that industry sector context moderates the effects of ESE and ET on decisions to quit or persist, possibly due to differences in complexity and administrative challenges. For practitioners, this means entrepreneurs, mentors, and investors should be cautioned about overreliance on entrepreneurial zeal for launching the new venture. Moreover, the specific nuanced potential for exuberance to manifest as ESE and/or ET in a context where such traits may not be altogether helpful, is a risk that all should give due consideration.

From an entrepreneurship pedagogy perspective, this study raises specific concerns about what sort of positive psychological development may be most beneficial for nascent entrepreneurs pursuing new ventures in different contexts. Social cognitive theory suggests that individuals initiating goal-directed behavior integrate information about personal skills and abilities into their predictions about the likelihood of success (Bandura, 2001). For this reason, it seems logical to pursue positive pedagogical interventions to alleviate self-doubt and build self-confidence in one's potential to achieve positive outcomes. However, the finding of an inverse curvilinear relationship suggests that there is an upper limit to how much ESE is needed. If the benefits of further pedagogical interventions to boost ESE are negligible, due to diminishing returns or reduced industry context relevance, then it might be better to focus on building strengths in other areas. Likewise, if follow-on studies support the finding that tenacity matters more for launching manufacturing ventures, an industry sector of national strategic importance for policy makers, then it seems intuitive that pedagogical interventions should be designed to 1) build task resilience, 2) build psychological coping skills, 3) provide realistic previews about the extent and duration of task complexities, and 4) facilitate social support to boost the entrepreneur's endurance for new manufacturing startup launches. 
This study also has important implications for researchers. For example, one could theorize that retail and services types of business formations may require more direct selling attempts, rejected offers, and negative interactions with potential customers such that a deep-seated sense of self-efficacy may facilitate resilience and perseverance. Studies examining the effect of self-efficacy on sales performance among sales people selling real estate, billboard advertisements, and cell phone messaging services, found strongly significant relationships (Krishnan et al., 2002; Wang \& Netemeyer, 2002). Extensive prior work has shown that different personality traits have different relationships with job performance in different types of jobs (Barrick \& Mount, 1991); however, this level of nuance is still needed in the entrepreneurial context because different types of new ventures have different types of job demands and other characteristics. At a minimum, it seems clear that the personality traits of nascent entrepreneurs seem to have different relationships with persistence behavior at the prelaunch phase in different business environment contexts.

\section{Conclusions, Limitations and Future Directions}

In response to the research question stated at the beginning of this paper, the empirical results provide preliminary evidence that different entrepreneurial personality characteristics have different, and curvilinear, relationships with quitting versus persisting in the pre-launch phase, and these differences seemingly depend on startup industry context. This paper also identifies entrepreneurial persistence in new venture creation as a critical construct of interest for studying opportunity exploitation in the pre-launch phase. Responding to the call by Welter (2011), these findings highlight the need for more research on the interplay between entrepreneurial traits and context at different stages of the new business formation lifecycle. While this provides an opportunity for future studies, it also raises serious concerns about the ability to generate universal theories of the role of individual characteristics in the entrepreneurship context. That is, it may be unrealistic to generate theories that would be universally applicable across the wide industry contexts in which entrepreneurship exists in the real world. Future studies must carefully consider the context of entrepreneurship while modeling entrepreneurial behavior.

While this study contributes meaningfully to the entrepreneurship literature, several limitations present important opportunities for follow-on studies. First, ESE and ET represent a small subset of the traits that may hold significance across different industry contexts and lifecycle stages. Scholars studying leadership within other domains of organization sciences have identified other relevant personality dimensions and individual differences and how they matter in different contexts. Since this study relied on the archival PSED-II dataset, there is no realistic possibility of expanding the 
constructs or modifying the measurement criteria to include additional survey items. One approach for developing new empirical studies at the pre-launch phase includes tapping into entrepreneur samples residing in various municipal, regional, and university incubator programs. Another approach the current authors are currently engaged with is obtaining nascent entrepreneur samples from groups that organize regular in-person meetings using various social media groups and applications.

Finally, while the current study builds on prior research examining characteristics such as education, experience, and other factors (Hopp \& Sonderegger, 2015; Sreih, Assaker \& Hallak, 2016), the ROC models in this study were only able to correctly classify a majority (up to $77.68 \%$, not all) of cases of quitting versus persisting. Other factors future scholars might consider include motivation, general mental ability, access to resources and financial capital, and other significant prior accomplishments that may serve as adequate proxies for ability.

\section{REFERENCES}

Baker, T., Gedajlovic, E., \& Lubatkin, M. (2005). A framework for comparing entrepreneurship across nations. Journal of International Business Studies, 36(5), 492-504. https://doi.org/10.1057/palgrave.jibs.8400153

Bandura, A. (2001). Social cognitive theory: An agentic perspective. Annual Review of Psychology, 52(1), 1-26. https://doi.org/10.1146/annurev.psych.52.1.1

Baron, R. A. (2007). Entrepreneurship: A process perspective. In The Psychology of Entrepreneurship. Eds. J. R. Baum, M. Frese, \& R. A. Baron. New York, N. Y., Psychology Press.

Barrick, M. R., \& Mount, M. K. (1991). The big five personality dimensions and job performance: A meta-analysis. Personnel Psychology, 44(1), 1-26. https://doi.org/10.1111/j.1744-6570.1991.tb00688.x

Baughn, C. C., Cao, J. S. R., Le, L. T. M., Lim, V. A., \& Neupert, K. E. (2006). Normative, social and cognitive predictors of entrepreneurial interest in China, Vietnam and the Philippines. Journal of Developmental Entrepreneurship, 11(1), 57-77. https://doi.org/10.1142/s108494670600026x

Baum, J. R., \& Locke, E. A. (2004). The relationship of entrepreneurial traits, skill, and motivation to subsequent venture growth. Journal of Applied Psychology, 89, 587598. https://doi.org/10.1037/0021-9010.89.4.587

Baum, J. R., Locke, E. A., \& Smith K.G. (2001). A multidimensional model of venture growth. Academy of Management Journal, 44(2), 292-303. https://doi.org/10.5465/3069456 
Beesley, C. (2013). Sole proprietorship - Is this popular business structure right for you?. Blogs -Starting a Business, SBA. http://www.sba.gov/blogs/soleproprietorship-popular-business-structure-right-you (accessed July 21, 2017).

Boettke, P., \& Coyne, C. (2009). Context matters: Institutions and entrepreneurship. Foundations and Trends in Entrepreneurship, 5(3), 135-209. https://doi.org/10.1561/0300000018

Cardon, M. S., \& Kirk, C. P. (2015). Entrepreneurial passion as mediator of the selfefficacy to persistence relationship. Entrepreneurship Theory and Practice, 39(5), 1027-1050. https://doi.org/10.1111/etap.12089

Cassar, G., \& Friedman, H. (2009). Does self-efficacy affect entrepreneurial investment?. Strategic Entrepreneurship Journal, 3(3), 241-260. https://doi.org/10.1002/sej.73

Chandler, G. N., \& Jansen, E. (1992). The founder's self-assessed competence and venture performance. Journal of Business Venturing, 7(3), 223-236. https://doi.org/10.1016/0883-9026(92)90028-p

Chen, C. C., Greene, P. G., \& Crick, A. (1998). Does entrepreneurial self-efficacy distinguish entrepreneurs from managers?. Journal of Business Venturing, 13(4), 295-316. https://doi.org/10.1016/s0883-9026(97)00029-3

Cheng, L. J., \& Liao, C. C. (2017). The drivers of entrepreneurial intention: The role of social capital and overconfidence. Contemporary Management Research, 13(2), 143-162. https://doi.org/10.7903/cmr.17589

Curtin, R. (2012). Panel study of entrepreneurial dynamics II screener + Wave A - Wave F codebook. Retrieved from panel study of entrepreneurial dynamics. University of Michigan. www.psed.isr.umich.edu

Curtin, R., \& Reynolds, P. D. (2018). Panel Study of Entrepreneurial Dynamics, PSED II, United States, 2005-2011. Ann Arbor, MI: Inter-university Consortium for Political and Social Research, https://doi.org/10.3886/ICPSR37202.v1

Davidsson, P. (2012). Engagement, persistence, progress and success as theoretically distinct aspects of business creation processes. Frontiers of Entrepreneurship Research, Babson College.

Davidsson, P., \& Gordon, S. R. (2012). Panel studies of new venture creation: A methods-focused review and suggestions for future research. Small Business Economics, 39(4), 853-876. https://doi.org/10.1007/s11187-011-9325-8

Demirguc-Kunt, A., Love, I., \& Maksimovic, V. (2006). Business environment and the incorporation decision. Journal of Banking \& Finance, 30(11), 2967-2993. https://doi.org/10.1016/j.jbankfin.2006.05.007

Dess, G. G., \& Beard, D. W. (1984). Dimensions of organizational task environments. Administrative Science Quarterly, 29(1), 52-73. https://doi.org/10.2307/2393080 
DeTienne, D. R., Shepherd, D. A., \& De Castro, J. O. (2008). The fallacy of "Only the strong survive": The effects of extrinsic motivation on the persistence decisions for under-performing firms. Journal of Business Venturing, 23(5), 528-546. https://doi.org/10.1016/j.jbusvent.2007.09.004

Dimov, D. (2010). Nascent entrepreneurs and venture emergence: Opportunity confidence, human capital, and early planning. Journal of Management Studies, 47(6), 1123-1153. https://doi.org/10.1111/j.1467-6486.2009.00874.x

Duckworth, A. L., Peterson, C., Matthews, M. D., \& Kelly, D. R. (2007). Grit: Perseverance and passion for long-term goals. Journal of Personality and Social Psychology, 92(6), 1087-1101. https://doi.org/10.1037/0022-3514.92.6.1087

Drnovšek, M., Wincent, J., \& Cardon, M. S. (2010). Entrepreneurial self-efficacy and business start-up: Developing a multi-dimensional definition. International Journal of Entrepreneurial Behavior \& Research, 16(4), 329-348. https://doi.org/10.1108/13552551011054516

Farmer, S. M., Yao, X., \& Kung-Mcintyre, K. (2011). The behavioral impact of entrepreneur identity aspiration and prior entrepreneurial experience. Entrepreneurship Theory and Practice, 35(2), 245-273. https://doi.org/10.1111/j.1540-6520.2009.00358.x

Gartner, W. B. (2004). Handbook of entrepreneurial dynamics: The process of business creation. Thousand Oaks, CA., Sage Publications. https://doi.org/10.4135/9781452204543

Gatewood, E. J., Shaver, K. G., \& Gartner, W. B. (1995). A longitudinal study of cognitive factors influencing start-up behaviors and success at venture creation. Journal of Business Venturing, 10(5), 371-391. https://doi.org/10.1016/08839026(95)00035-7

Gimeno, J., Folta, T. B., Cooper, A. C., \& Woo, C. Y. (1997). Survival of the fittest? Entrepreneurial human capital and the persistence of underperforming firms. Administrative Science Quarterly, 450-783. https://doi.org/10.2307/2393656

Hmieleski, K. M., \& Baron, R. A. (2006). Optimism and environmental uncertainty: Implications for entrepreneurial performance. Frontiers of Entrepreneurship Research. Babson College.

Hmieleski, K. M., \& Baron, R. A. (2008). When does entrepreneurial self-efficacy enhance versus reduce firm performance?. Strategic Entrepreneurship Journal, 2(1), 57-72. https://doi.org/10.1002/sej.42 
Hmieleski, K. M., \& Baron, R. A. (2009). Entrepreneurs' optimism and new venture performance: A social cognitive perspective. Academy of Management Journal, 52(3), 473-488. https://doi.org/10.5465/amj.2009.41330755

Holland, D. V., \& Shepherd, D. A. (2013). Deciding to persist: Adversity, values, and entrepreneurs' decision policies. Entrepreneurship Theory and Practice, 37(2), 331-358. https://doi.org/10.1111/j.1540-6520.2011.00468.x

Hopp, C., \& Sonderegger, R. (2015). Understanding the dynamics of nascent entrepreneurship — prestart-up experience, intentions, and entrepreneurial success. Journal of Small Business Management, 53(4), 1076-1096. https://doi.org/10.1111/jsbm.12107

Hurst, C. G. (2019). An axiological measure of entrepreneurial cognition. International Journal of Entrepreneurial Behavior \& Research. 25(2), 394-412. https://doi.org/10.1108/ijebr-05-2018-0337

Kickul, J., Gundry, L. K., Barbosa, S. D., Whitcanack, L., Lyon, E., \& France G. (2009). Intuition versus analysis? Testing differential models of cognitive style on entrepreneurial self-efficacy and the new venture creation process. Entrepreneurship Theory and Practice, 33(2), 439-453. https://doi.org/10.1111/j.1540-6520.2009.00298.x

Kim, P. H., Aldrich, H. E., \& Keister, L. A. (2006). Access (not) denied: The impact of financial, human, and cultural capital on entrepreneurial entry in the United States. Small Business Economics, 27(1), 5-22. https://doi.org/10.1007/s11187-0060007-x

Krishnan, B. C., Netemeyer, R. G., \& Boles, J. S. (2002). Self-efficacy, competitiveness, and effort as antecedents of salesperson performance. Journal of Personal Selling and Sales Management, 22(4), 285-295. https://doi.org/10.1080/08853134.2002.10754315

Liao, J., \& Welsch, H. (2004). Entrepreneurial intensity. In W. B. Gartner, K. G. Shaver, N. M. Carter, \& P. D. Reynolds (Eds.), Handbook of Entrepreneurial Dynamics: The Process of Business Creation, Sage Publications. https://doi.org/10.4135/9781452204543.n17

Lin, T. L., Lu, T. Y., Hsieh, M. C., \& Liu, H. Y. (2018). From conception to start-up: Who and what affect female entrepreneurship. Contemporary Management Research, 14(4), 253-276. https://doi.org/10.7903/cmr.17957

Markman, G. D. (2007). Entrepreneurs' competencies. In The Psychology of Entrepreneurship, Eds. J. R. Baum, M. Frese, \& R. A. Baron. New York, N. Y., Psychology Press. 
Markman, G. D., \& Baron, R. A. (2003). Person-entrepreneurship fit: Why some people are more successful as entrepreneurs than others. Human Resource Management Review, 13(2), 281-301. https://doi.org/10.1016/s1053-4822(03)00018-4

Markman, G. D., Baron, R. A., \& Balkin, D. B. (2005). Are perseverance and selfefficacy costless? Assessing entrepreneurs' regretful thinking. Journal of Organizational Behavior, 26(1), 1-19. https://doi.org/10.1002/job.305

McGee, J. E., Peterson, M., Mueller, S. L., \& Sequeira, J. (2009). Entrepreneurial selfefficacy: Refining the measure. Entrepreneurship Theory and Practice, 33(4), 965-988. https://doi.org/10.1111/j.1540-6520.2009.00304.x

Meek, W., \& Williams, D. W. (2018). Venture creation persistence: Overcoming stagegate issues. International Journal of Entrepreneurial Behavior and Research, 24(5), 1016-1035. https://doi.org/10.1108/ijebr-08-2016-0270

Mischel, W. (1977). On the future of personality measurement. American Psychologist, 32(4), 246-254. https://doi.org/10.1037//0003-066x.32.4.246

Mischel, W., \& Shoda, Y. (1995). A cognitive-affective system theory of personality: Reconceptualizing situations, dispositions, dynamics, and invariance in personality structure. Psychological Review, 102(2), 246-268. https://doi.org/10.1037//0033-295x.102.2.246

Rauch, A., \& Frese, M. (2007). Let's put the person back into entrepreneurship research: A meta-analysis on the relationship between business owners' personality traits, business creation, and success. European Journal of Work and Organizational Psychology, 16(4), 353-385. https://doi.org/10.1080/13594320701595438

Schjoedt, L., \& Craig, J. B. (2017). Development and validation of a unidimensional domain-specific entrepreneurial self-efficacy scale. International Journal of Entrepreneurial Behavior \& Research, 23(1), 98-113. https://doi.org/10.1108/ijebr-11-2015-0251

Seligman, M. E. P., \& Schulman, P. (1986). Explanatory style as a predictor of productivity and quitting among life insurance sales agents. Journal of Personality and Social Psychology, 50(4), 832-838. https://doi.org/10.1037//00223514.50.4.832

Shane, S., \& Venkataraman, S. (2000). The promise of entrepreneurship as a field of research. Academy of Management Review, 25(1), 217-226. https://doi.org/10.5465/amr.2000.2791611

Shaver, K. G., Gatewood, E. J., \& Gartner, W. B. (1992). Attributions for new venture creation: An experimental comparison", Frontiers of Entrepreneurship Research, Babson College. 
Sreih, J. F., Assaker, G., \& Hallak, R. (2016). Entrepreneurial experience, support for community and family firm performance: A cross-study of product and servicebased family businesses. Contemporary Management Research, 12(4), 467-496. https://doi.org/10.7903/cmr.15360

Stewart, W. H., \& Roth, P. L. (2001). Risk propensity differences between entrepreneurs and managers: A meta-analytic review", Journal of Applied Psychology, 86(1), 145-153. https://doi.org/10.1037//0021-9010.86.1.145

Stajkovic, A., \& Luthans, F. (1998), Self-efficacy and work-related performance: A meta-analysis. Psychological Bulletin, 124(2), 240-261. https://doi.org/10.1037/0033-2909.124.2.240

Stoltz, P. G. (1997). Adversity quotient: Turning obstacles into opportunities. United States, John Wiley and Sons, Inc.

Tang, J. (2008). Environmental munificence for entrepreneurs: Entrepreneurial alertness and commitment. International Journal of Entrepreneurial Behavior \& Research, 14(3), 128-151. https://doi.org/10.1108/13552550810874664

Tenacity (n.d.) In Merriam-Webster online dictionary, Retrieved May 22, 2018 from https://www.merriam-webster.com/

Trevelyan, R. (2011). Self-regulation and effort in entrepreneurial tasks. International Journal of Entrepreneurial Behavior \& Research, 17(1), 39-63. https://doi.org/10.1108/13552551111107507

van Gelderen, M. (2012). Perseverance strategies of enterprising individuals. International Journal of Entrepreneurial Behavior \& Research, 18(6), 630-648. https://doi.org/10.1108/13552551211268102

Wang, G., \& Netemeyer, R. G. (2002). The effects of job autonomy, customer demandingness, and trait competitiveness on salesperson learning, self-efficacy, and performance. Journal of the Academy of Marketing Science, 30(3), 217-228. https://doi.org/10.1177/00970302030003003

Welter, F. (2011). Contextualizing entrepreneurship-conceptual challenges and ways forward. Entrepreneurship Theory and Practice, 35(1), 165-184. https://doi.org/10.1111/j.1540-6520.2010.00427.x

Wu, S., \& Dagher, G. K. (2007). Need for achievement, business goals, and entrepreneurial persistence. Management Research News, 30(12), 928-941. https://doi.org/10.1108/01409170710833358

Zhao, H., \& Seibert, S. E. (2006). The big five personality dimensions and entrepreneurial status: A meta-analytical review. Journal of Applied Psychology, 91(2), 259-271. https://doi.org/10.1037/0021-9010.91.2.259 
Zhao, H., Seibert, S. E. \& Hills, G. E. (2005). The mediating role of self-efficacy in the development of entrepreneurial intentions. Journal of Applied Psychology, 90(6), 1265-1272. https://doi.org/10.1037/0021-9010.90.6.1265

Dr. James R. Van Scotter II (Corresponding author) is currently an Assistant Professor of Strategy in the College of Business at University of Colorado Colorado Springs. His research interests include strategic leadership, top executive individual differences and personality, behavioral research methods, positive organizational psychology, and the influence of contextual factors on performance outcomes. His recent research has been published in the Journal of Business Ethics, Journal of Vocational Behavior, Management Review Quarterly, and the International Journal of Human Resources Management.

Dr. Swapnil Garg is currently a Professor of Strategic Management at the Indian Institute of Management, Indore. His research interests include entrepreneurship, public-private partnerships, relational governance, contract coordination mechanisms, alliance management, and monopsony markets. His recent research has been published in the Journal of Public Affairs and the Journal of Business Ethics. 